\title{
山間部のダム湖周辺地域における夏季屋外気温分布に関する研究
}

\section{Spatial Patterns of Outdoor Temperatures in a Surrounding Area of a Dam in a Mountainous Region}

\author{
田中 貴宏* 村川 三郎* 西名 大作* 深川 健太** \\ Takahiro TANAKA Saburo MURAKAWA Daisaku NISHINA Kenta FUKAGAWA
}

\begin{abstract}
Adapting cities and regions to climate change is becoming an important issue in the field of landscape planning. Mitigating summer outdoor temperature is one of the adaptations. Using the cooling effect of water bodies is one of the measures for the mitigations. Consequently, this study was conducted to clarify the spatial distributions of a dam's cooling effect and to compare the cooling effects by natural features including dam hourly, using the field measurement data collected in the surrounding residential area of Fukutomi Dam in Higashihiroshima. Results show the followings. 1) The dam's cooling effect is greater during the daytime. 2) The cooling affects areas locate leeward and within $500 \mathrm{~m}$ of the dam. 3) Stronger winds produce greater cooling effects. Additional measurements must be taken at the other dams to clarify general dam's cooling effects. As a final goal, recommendations for landscape design in such areas must be produced.
\end{abstract}

Keywords: Dam, Outdoor temperature, Field temperature measurement, Mountainous region, GIS キーワード：ダム湖，屋外気温，気温観測，山間部，GIS

\section{1. はじめに}

近年，地域や都市における気候変動適応の必要性が指摘されて おり，その適応のひとつとして，夏季屋外の暑熱緩和が挙げられ ている 1)。この暑熱緩和策には様々あるが，緑地，風，水面とい った自然環境資源が有する気温低減作用の活用が，そのひとつと して挙げられる。緑地や風による暑熱緩和効果については, 多く の研究がなされており, 一般向け書籍 2)などでもそれらの成果が まとめられている。また，水面については，河川，池，ダム湖等 が周囲に及ぼす効果について研究がなされている。特に河川に関 しては多くの研究があり，沿岸部に位置する福岡 3)，東京 4)での 観測を通して，河川の「風の道」としての効果の検討を行ったも の，同じく沿岸部に位置する広島 5)や東京 6)での観測を通して, 河川が周辺市街地に及ぼす熱的影響の検討を行ったものなどがあ る。また，池等の比較的小さな水面についても福岡 7), 東広島 8) での観測を通して，周辺市街地の気温等の熱環境に及ぼす影響の 調査を行ったものなどがある。さらに，池については数值モデル を用いた気候緩和影響範囲の検討 9)も行われている。これら既往 研究の成果より, 水面が周辺市街地に対して暑熱緩和効果を有し ていることは明らかであり，そのメカニズムとしては，水面自体 の冷気生成以外にも, 粗度が小さいことによる風の誘導などが複 合的に作用した結果であるといえる。

ダム湖は水面の規模が大きく，より大きな暑熱緩和効果を有す ると考えられるが，地域・都市計画関連分野では，数值モデルを 活用しダム開発による温熱環境への影響を調查した研究 10)以外 は, ダム湖の気温低減作用に着目した研究はほとんど見られない。 一方, 農業分野では, ダム湖が周辺気温に及ぼす影響の調查が行 われている 11)12)。しかしこれらは農作物の寒害対策や消流雪等, 冬季の低温対策に主眼があり，周辺市街地の暑熱緩和効果を検討 したものではない。

近年，本研究の対象地のように，山間部のダム湖周辺に市街地 が形成されるケースも見られ，そのような市街地の気候変動適応
という観点からも，ダム湖の有する暑熱緩和効果を明らかにする 必要があるものと考えられる。そこで本研究では，広島県東広島 市福富町の福富ダム周辺地域を対象に, 湛水前後の夏季気温分布 観測を行い，(1)ダム湖の有する暑熱緩和効果を空間的に把握寸る こと, および(2)ダム湖とその他の自然環境要因が気温分布に及ぼ す影響の相互比較を行うことを目的とした。なお，同一の対象地 で, 湛水前後の気温分布比較を行った点に, 本研究のひとつの特 徵があると考えられる。

\section{2. 研究概要}

\section{(1) 対象地概要}

本研究では，東広島市北部の福富町に位置する福富ダム周辺を 対象とした（図一1)。福富ダムは, 二級河川である沼田川に建設 された多目的ダム（湛水面積 : 約 70ha）で，2008 年 10 月にダ ム本体が完成し，2009 年 3 月に湛水が完了した。またダム建設 に伴い，周辺地域では，水没地域居住者や新規転入者のための住 宅地整備, 道路整備, 道の駅整備等が行われた。

\section{(2) 測定概要}

気温の測定は，湛水前である 2008 年夏季（8月 1 日〜 7 日), および湛水後である 2009 年夏季 (8月 1 日〜24 日)に実施した。 測定地点を図一 1 に示す。 2008 年は 25 地点（測定地点 1 25), 2009 年はさらに 12 地点 (測定地点 26〜37) を追加し 37 地点で, それぞれ気温測定を行った。測定地点 1〜9では, ファンにより 強制通風させた小型百葉箱内に，また測定地点 10 ～37 では，フ アンにより強制通風させた放射シールド内に，それぞれデータロ ガー付温湿度センサー（エスペック社 : TR-72S）を設置した。 なお，測定間隔は 5 分，設置高さは地上 $1.5 \mathrm{~m}$ とした。

また測定地点 A では, 風向風速計(R. M. Young 社:CYG-5103), および日射計（英弘精機 : MS-602) を設置し, 風向, 風速, 日 射量の測定を行った。なお測定間隔は, 風向・風速は 10 分, 日 射量は 1 分とした。さらに測定地点 B では，2009 年夏季にダム

*広島大学大学院工学研究科豛九州産業大学建築都市工学部 
湖水面下 $10 \mathrm{~cm}$ の水温を測定した。

なお，航空写真で確認したところ，2008 年と 2009 年の測定の 間に，自然被覆から人工被覆への土地被覆変化，およびその逆の 土地被覆変化は見られなかった。

\section{3. 気象概況}

\section{（1）気温，日射量，ダム湖水温}

周辺の市街化が進んでおらず，また，ダム湖より $1 \mathrm{~km}$ 程度離 れているため，ダム湖の影響を受けにくいと考えられる測定地点 1 (標高 357m) を基準点とし, 同地点における, 2006 年から 2009 年までの夏季晴天日の時刻別平均気温を図一 2 に示寸 13$)$ 。なお晴 天日の判定には, 対象地から南南西方向約 $15 \mathrm{~km}$ に位置する広島 大学で測定した日射量のデータ 14)を用い，日積算日射量が $20 \mathrm{MJ} / \mathrm{m}^{2}$ 以上の日を晴天日とした。2008 年は，2006 年や 2007 年とほぼ同様の傾向であり，標準的な年であったと考えられる。

一方，2009年は他の年に比べて昼間の気温がやや低い。

2008 年および 2009 年の測定期間における時積算日射量 (測定 地点 $\mathrm{A}$ ), 気温 (基淮点: 測定地点 1), ダム湖水温（測定地点 B,

2009 年のみ) の時間変動を図一 3 に示す。なお， 2009 年は 24 日間の観測を行ったので，代表として，最も天候が安定していた 8 月 17 日〜 24 日を示す。また参考として，対象地から西南西方 向約 $33 \mathrm{~km}$ に位置する広島地方気象台 (広島市)（標高 $4 \mathrm{~m} ）$ にお ける同一期間の気温変動をあわせて示す。気温については，両年 とも広島市に比べ夜間の気温が特に低いこと, 昼間の気温が広島 市と同程度になる日があること，2009 年は昼間の最高気温が $32^{\circ} \mathrm{C}$ 達しないことなどが傾向として挙げられる。また日射量に ついは，2008 年の方が若干大きいこと，水温については $23^{\circ} \mathrm{C}$ ～ $26^{\circ} \mathrm{C}$ 間で変動していることなどが特徴として挙げられる。水 温の変動幅がやや大きい印象だが，これは測定水深が浅いためと 考えられる。また，水温測定に際しては，日射遮蔽等の工夫は行 っておらず，そのため，昼間の水温は日射の影響も受けているも のと考えられる。なお, 2009 年 8 月 1 日〜 8 月 16 日の晴天日は,

日射量と水温が 8 月 17 日〜24 日に比べやや低いが，他の傾向は 8 月 17 日〜 24 日と同様であった。

\section{（2）風向, 風速}

2008 年および 2009 年の測定期間における風向, 風速（測定地 点A）の時間変動を図一 4 に示す。なお，前節同様，2009年は代 表として 8 月 17 日〜24 日のみを示す。両年とも, 昼間は風速 $1.0 \mathrm{~m} / \mathrm{s}$ 以上の南方向の風が見られる日が，また夜間は北方向の微 風が見られる日がそれぞれ多い。なお，この傾向は 2009 年 8 月 1 日〜8 月 16 日の晴天日も同様であった。また，8月 20 日およ び 21 日の夜から翌朝は南寄りの風が卓越しているが，この時間 帯の福富町 (基淮点) 気温（図一-3）を見ると，他の日に比べ気 温が高く, ダム湖水温と同程度となっている。これはダム湖水温 がこの地域の夜間気温に比べ高いため，その熱が風下の夜間気温 を上昇させているものと推察される。

\section{4. ダム湖が周辺住宅地に及ぼす影響の分析 \\ (1) 湛水前後の気温分布の比較}

2008 年と 2009 年の昼間南寄りの風が見られる晴天日における, 5 時と 14 時の時刻別平均気温の分布を図一 5 に示寸。なお，平均 気温算出に用いた日数（日積算日射量が $20 \mathrm{MJ} / \mathrm{m}^{2}$ 以上で南風が 観測された日の日数) は, 2008 年が 6 日, 2009 年が 7 日である。 また比較のために，2009 年の図では，2008年に測定を行った測 定地点のみ示している。

5 時は，標準偏差が比較的小さく，また湛水前後の分布に顕著 な違いは見られない。このことから，この時間は湛水による影響 は小さいと考えられる。一方，14 時の分布を見ると，2009 年の

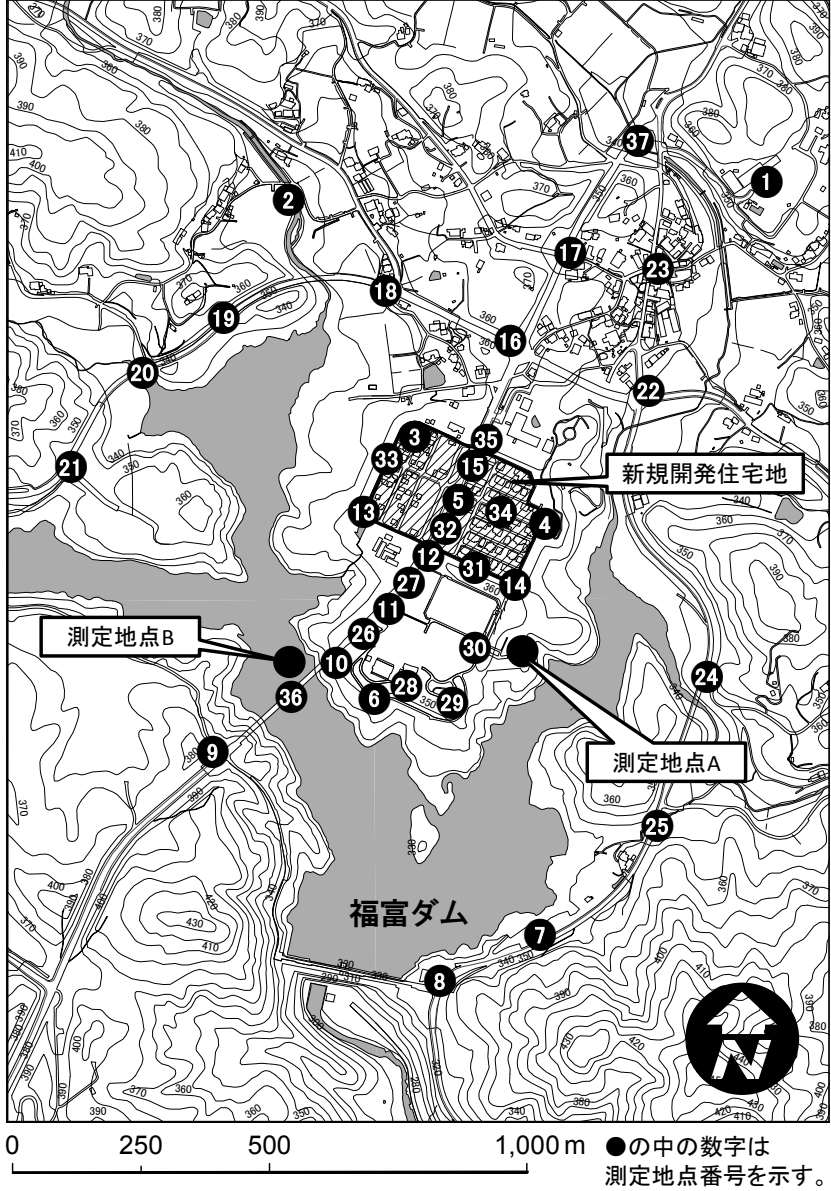

図-1 対象地と測定地点

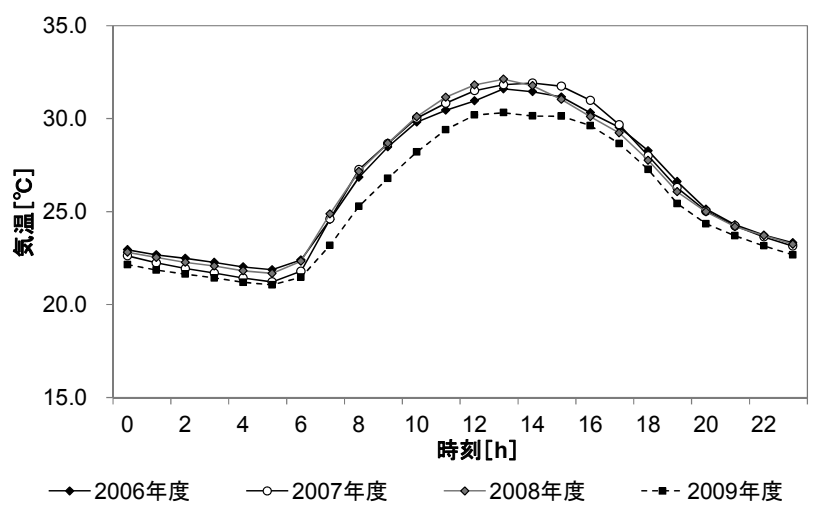

図一2 時刻別平均気温（測定地点 1)

みダム湖北部のエリア（測定地点 $6,10 ， 11 ， 12 ， 13 ， 14 ） の$ 気 温が一様に低いが, 2008 年は地点 6, 11, 13 で気温が高く, 2009 年と傾向が異なる。地形 (図一-1) をみると，このエリアが平坦 であることからも，これは南からの風により，ダム湖で生成され た冷気が，風下に運ばれた影響と考えられる。図一 3 のダム湖水 温と気温の関係とあわせて考察すると, ダム湖水温が低く, 比較 的風の強、昼間にダム湖の暑熱緩和効果が見られるものと考えら れる。なお，ダム湖に比較的近い地点 $18 ， 20 ， 22$ では，2009年 も気温が低下していない。これは, 風上方向となる南方向にダム 湖水面が少ないことが要因として考えられる。

\section{（2）ダム湖からの距離と気温の関連}

湛水前後それぞれについて, 各測定地点における 14 時の平均 気温の全測定地点平均值からの偏差を求め, さらに湛水前後のそ の值の差（湛水前後気温差）を算出した。その後，昼間の風が南 


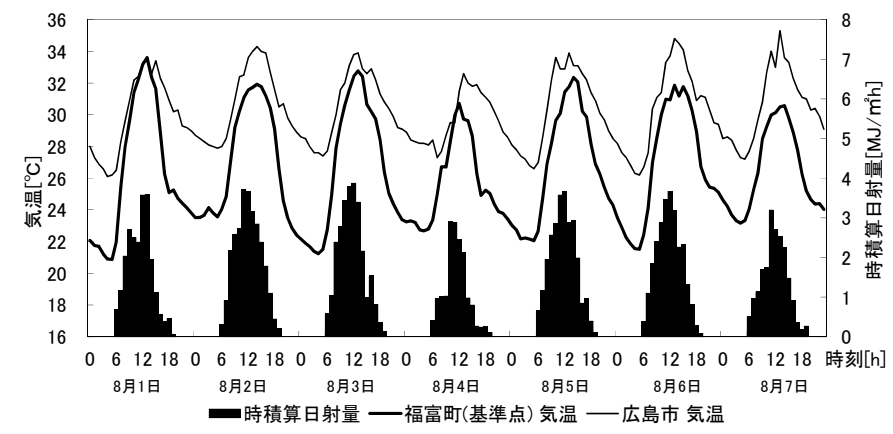

(a) 2008 年 (8月1日 7日)

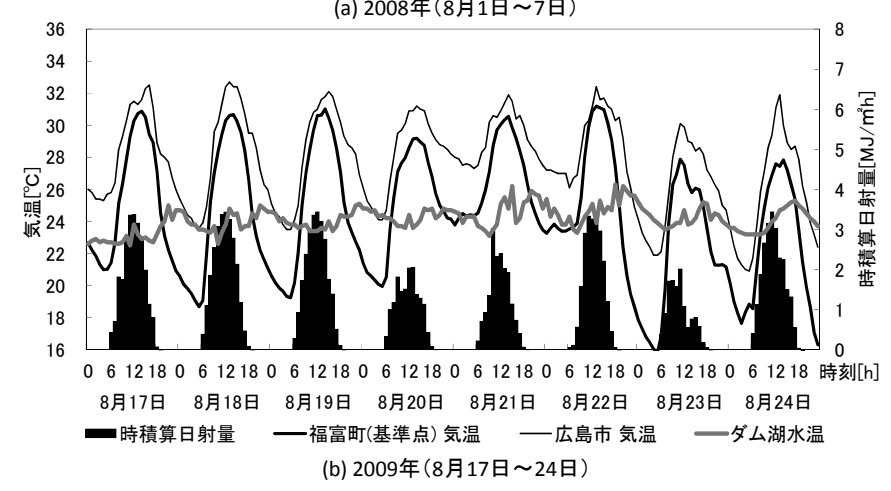

図一３観測期間の時積算日射量, 気温, ダム湖水温
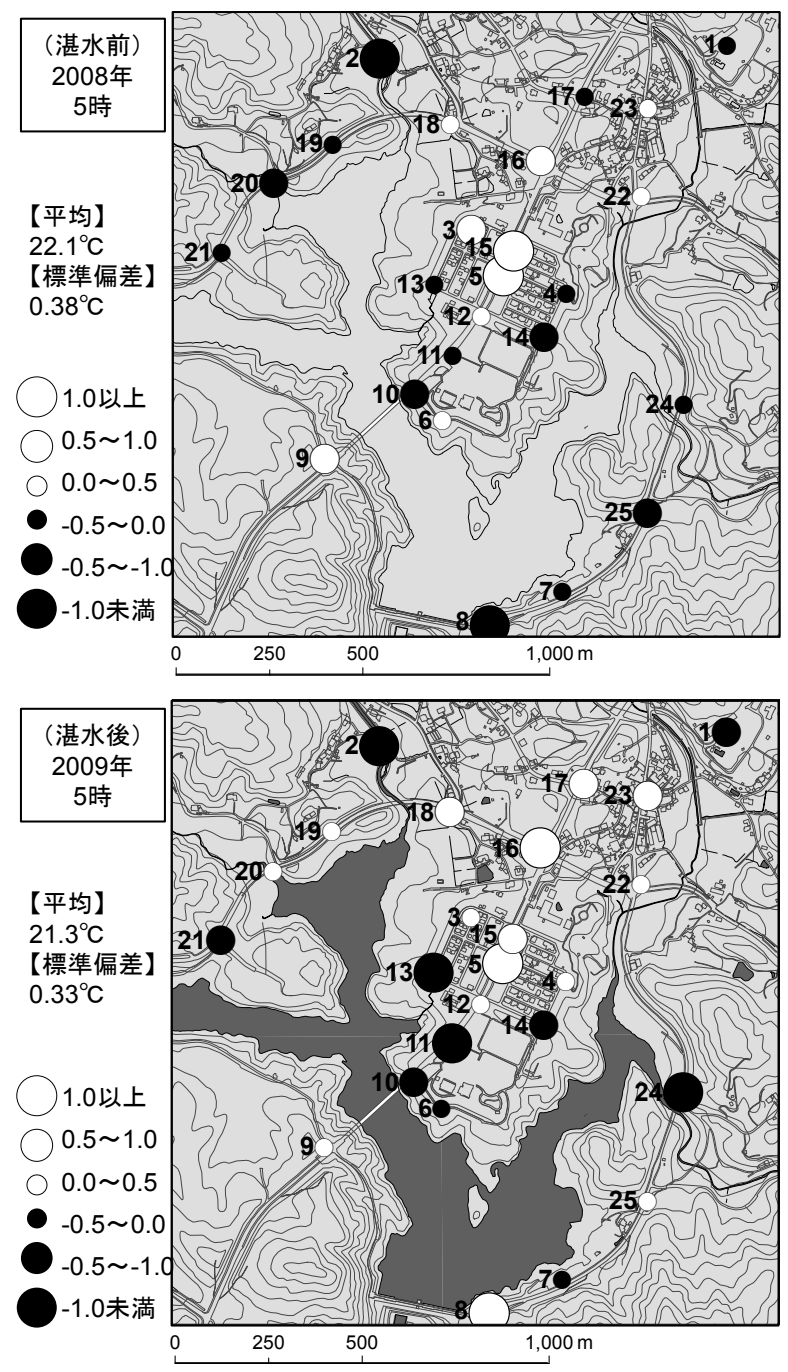

図一5 湛水前後の晴天日における時刻別平均気温分布（5 時，14 時)

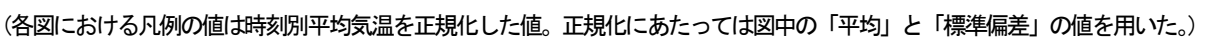

(a) 2008年 (8月1日〜 7日)

(b) 2009年 (8月17日〜24日)
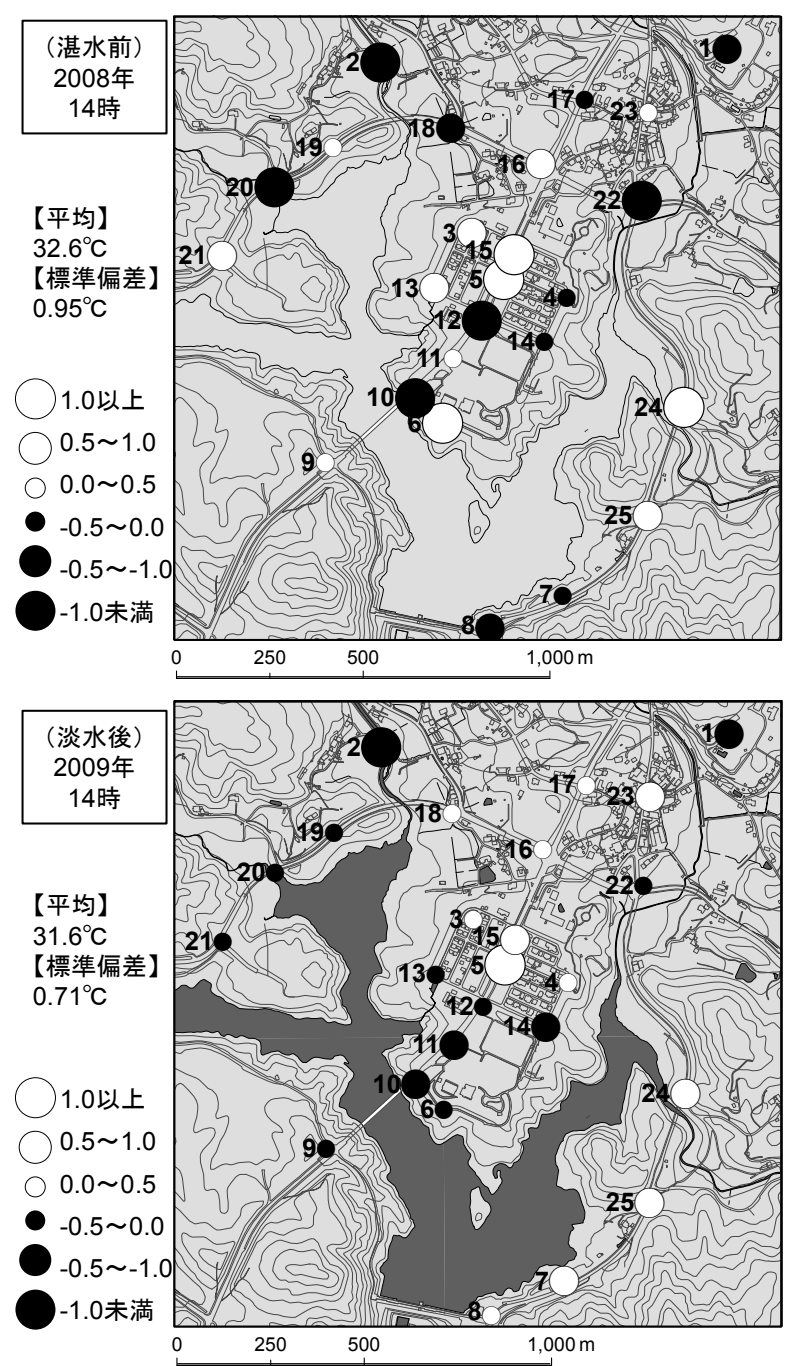
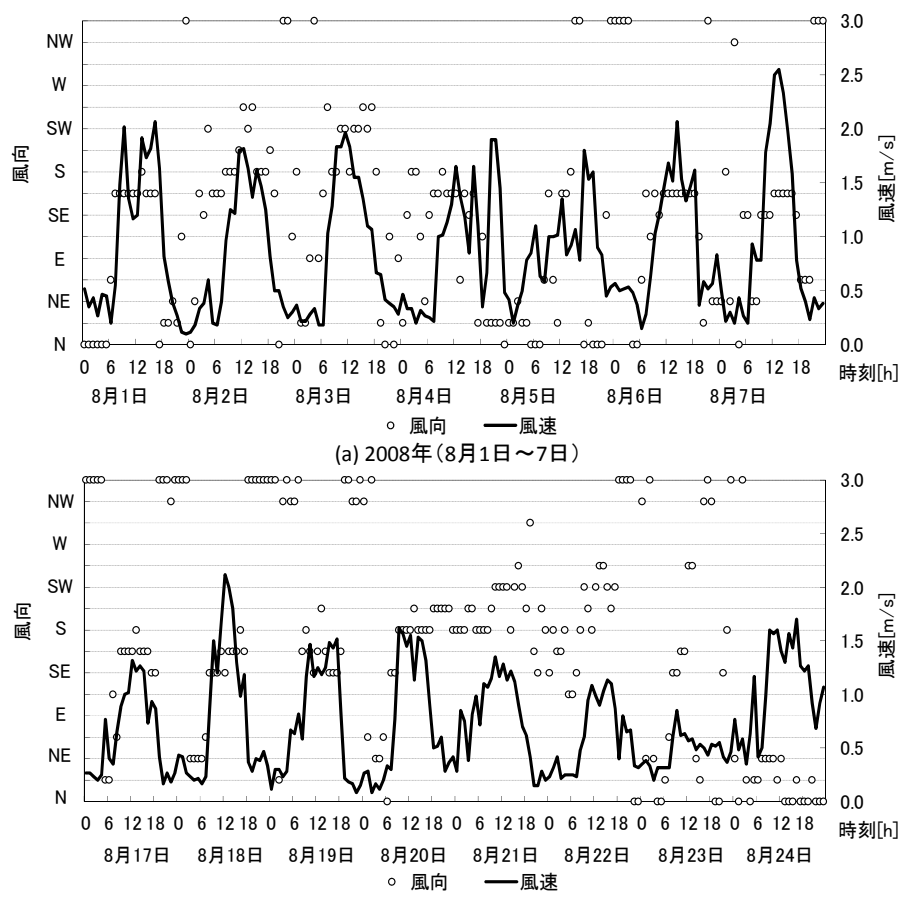

図-4 観測期間の風向 $・$ 風速（測定地点 $A ）$ 
方向であることから，ダム湖の北側の測定地点については南方向 のダム湖までの距離，南側の測定地点については北方向のダム湖 までの距離をそれぞれ「南北方向距離」として計測し，これを横 軸，湛水前後気温差を縦軸とし，各測定地点をプロットした図を 作成した (図一-6)。なお，ここでの湛水前後気温差は，2009 年 の值から 2008 年の值を引いたものである。

図一6 より，14 時の平均気温が相対的に低下している浿定地 点が，ダム湖からの距離約 $500 \mathrm{~m}$ 以内に集中していることが分か る。ただし, 測定地点 7,8 のようにダム湖の風上の測定地点で は，その傾向は見られない(寧ろ，上昇しており，これは湛水に より風の吹き方が変わったことが要因として推察される)。このこ とより, ダム湖の暑熱緩和効果の影響範囲は概秝風下 $500 \mathrm{~m}$ 程度 と考えられる。ダム湖同様, 水を貯留しているため池を対象に周 辺の夏季気温分布調査を行った既往研究 8) では, 昼間のため池 (満 水面積：2.5ha）の風下一の暑熱緩和効果が $200 \mathrm{~m}$ に及んでいな いことが示唆されており, また, 水田を対象に周辺の夏季気温分 布調查を行った既往研究 9)では, 昼間の水田の風下一の暑熱緩和 効果は水田縁から $150 \mathrm{~m} \sim 200 \mathrm{~m}$ 程度であると報告されている。

これらに比べ, 本研究で対象としたダム湖の風下側への影響は大 きい。一般的に，ダム湖は大きな水面，水量を有しているため， 暑熱緩和効果が大きく, その効果が及ぶ範囲もため池や水田に比 べ2 倍以上になり得るものと考えられる。

\section{（3）風速の違いによる気温分布の比較（2009 年 : 湛水後)}

2009 年の昼間（12 時〜16 時）において, 測定地点 A での 1 時間の最多風向が南寄り（南を中心に南東から南西まで）であっ た時間を抽出し，さらにそれらを 1 時間の平均風速が $1.0 \mathrm{~m} / \mathrm{s}$ 末 満のケースと, $1.5 \mathrm{~m} / \mathrm{s}$ 以上のケースに分け, 各ケースの平均気温 分布を算出した結果を図一 7 に示寸。なお図一 7 では, 各ケース における全測定地点の平均值を基準とし，0.5 $\mathrm{C}$ 刻みで，それぞれ シンボルの色と大きさを変えている。どちらのケースにおいても, ダム湖北部のエリア（測定地点 $6,10,11 ， 12 ， 14$ ) の気温が相 対的に低いが，風速が大きい方が，その低下幅が大きくなる（な お，同じくダム湖北部のエリアの地点 13 については, 風上方向 のダム湖水面までの距離があるため, 低下幅が大きくならなかっ たものと考えられる)。このことより, 風の強い昼間にダム湖の暑 熱緩和効果が，より大きく現れるものと考えられる。ただし，ど ちらにおいても, 測定地点 5 のような住宅地の中心部ではその効 果が見られない。また，風上に位置寸る測定地点 7,8 について もダム湖の暑熱緩和効果は見られない。図一1を見ると測定地点 7 の南側に山があり，地形効果によりこの部分に逆流が生じ，さ らにはその風がダム湖の冷熱を測定地点 7 にもたらす可能性も考 えられるが，南方向に開けている測定地点 8 と測定地点 7 の間に 大きな傾向の差が見られないことから，その可能性は低いと考え られる。これは山の横（測定地点 8 の方向）から回り込む風 15) の影響が相対的に大きいためと考えられる。一方，地点 9 は効果 が見られるが，これは地形効果により，局所的に逆流が生じ，ダ ム湖水面の冷熱が運ばれた結果と推察される。ただし, 風の流れ に関しては, 今後, $\mathrm{CFD}$ 等を用いて, 当該地域の風環境を把握す る必要がある。

\section{（4）風速が風上・風下の気温差に及ぼす影響の分析}

2009 年の晴天日の昼間（12 時〜16 時）において, 測定地点 A での 1 時間の最多風向が南寄り（南を中心に南東から南西まで） であった時間を対象に，まず，ダム湖に対して風下に位置する 12 の測定地点 $(3,4,5,6,10,11,12,13,14,15,16,17)$ それぞれについて，その地点の気温と風上に位置する 2 つの測定 地点 $(7,8)$ との平均気温の差 (以下, 風上風下気温差) を時間 毎に算出した。次に, 風速 (測定地点 $\mathrm{A}$ ) と風上風下気温差との, 湛水前後の相関係数を, 各測定地点について算出した結果を図一

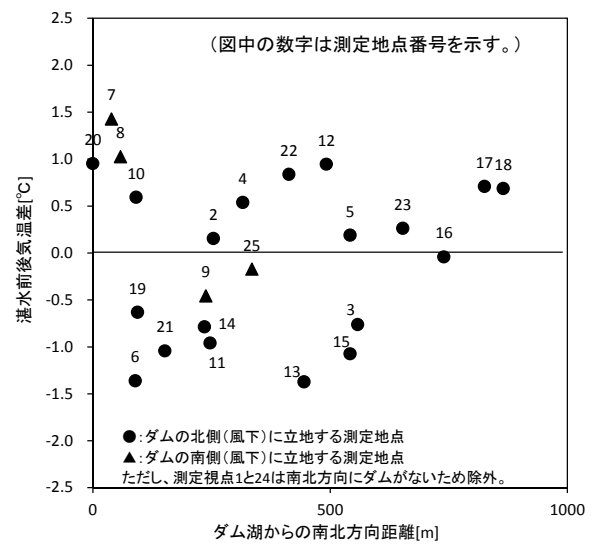

図一6 ダム湖からの南北方向距離と湛水前後気温差 （[湛水前後糸温差 $]=[2009$ 年值 $-[2008$ 年值 $]$
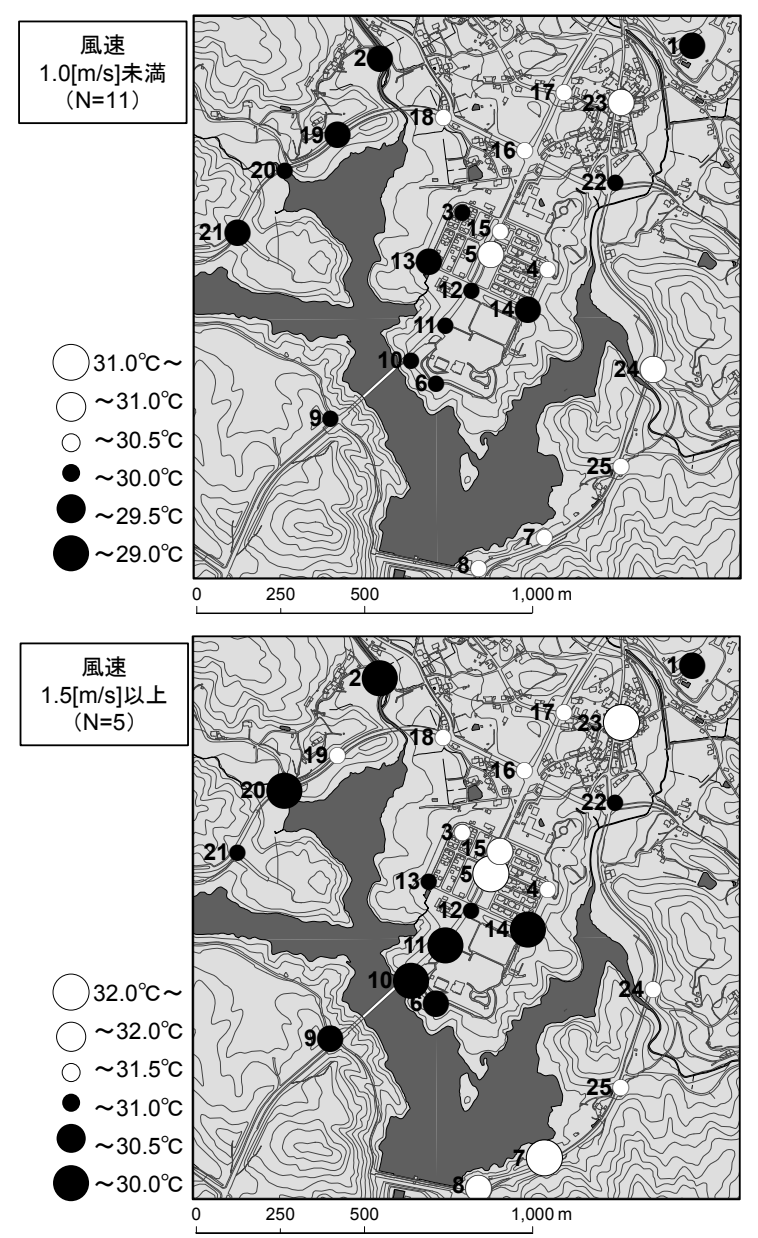

図-7 湛水後の風速別平均気温分布（南寄り風向卓越時）

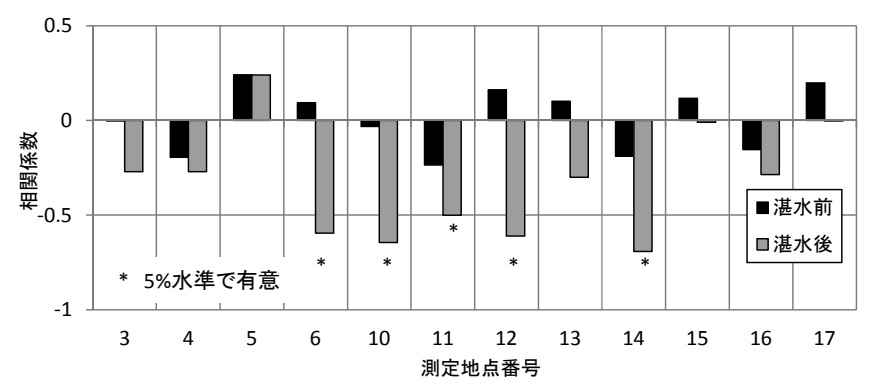

図-8＼cjkstart風速と風上風下気温差との相関係数 

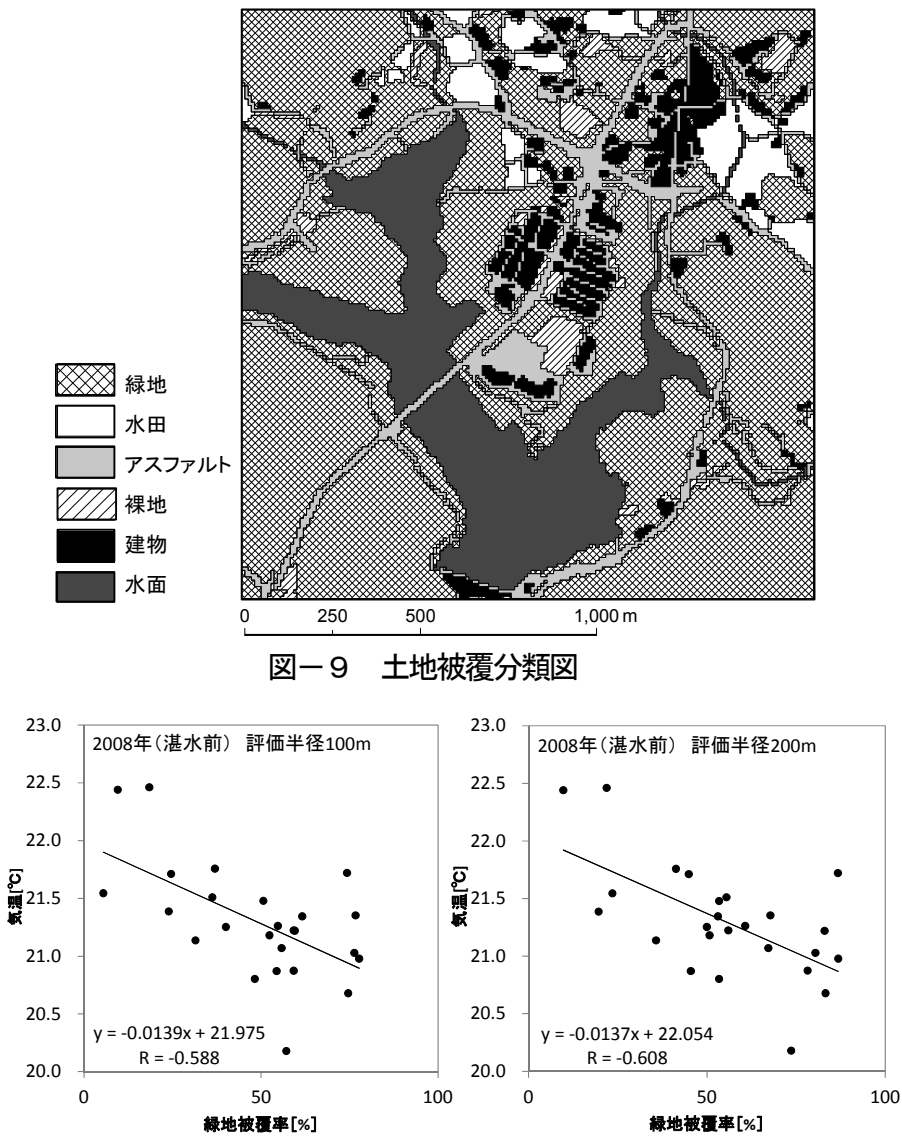

図一 10 緑地被覆率と 5 時の平均気温の関連 (緑地被覆率の評価半径 : 100m, 200m)

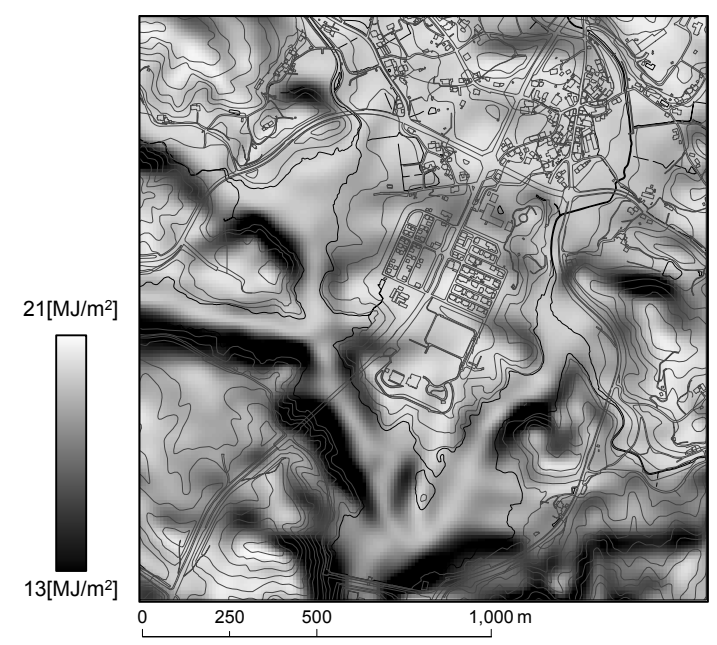

図-11 積算日射量分布 (2009 年 8 月 17 日 日没時)

\section{8 に示す。}

湛水前は，ほとんどの測定地点において，風速と風上風下気温 差との相関は見られない。一方，湛水後は，ダム湖に比較的近い 測定地点において風速と風上風下気温差との間に負の相関が見ら れる。特に, 前述のダム湖から約 $500 \mathrm{~m}$ 圏内の多くの測定地点 $(6$,

$10,11,12,14)$ では, 相関係数-0.5 - 0.6 と負の相関が比較的 大きい。また, ダム湖から約 $600 \mathrm{~m}$ 離れた測定地点 3,4 , 約 $800 \mathrm{~m}$ 離れた測定地点 16 では，相関係数- 0.3 程度の弱い負の相関が見 られ，約 $1 \mathrm{~km}$ 離れた測定地点 17 では相関が見られない。以上の ことから, ダム湖より約 $500 \mathrm{~m}$ 圈内では, 風速の増加にともなう 暑熱緩和効果の増大が見込め，また，この圏外となっても $800 \mathrm{~m}$
程度までであれば, ある程度効果が見込まれるものと考えられる。

\section{5. ダム湖が周辺住宅地に及ぼす影響の分析}

\section{（1）気温分布に影響を及ぼす要因の整理}

対象地の気温分布には, ダム湖以外の他の要因も影響している ものと考えられる。同じ対象地を扱った既往研究 16)では，土地被 覆と日射量が気温分布に対して影響を与えていることが示されて いる。そこで，これらの要因とダム湖の影響との相互比較を行う ために，図一 1 に示寸陸上の全測定地点をサンプルとし，以下の 変数を説明変数とした重回帰分析を行うこととした。

1）土地被覆（緑地）

対象地の土地被覆分類図を図 -9 亿示寸。なお, 図中の「緑地」 はほぼ樹木で構成されている。この図は, 航空写真 (縮尺 1/5000) に $10 \mathrm{~m} \times 10 \mathrm{~m}$ のメッシュを重称, 各メッシュの代表土地被覆を割 り当てたものである。これら土地被覆，特に緑地が気温に影響を 与えることはよく知られている。そこで測定地点周囲の緑地被覆 率を説明変数のひとつとした。なお, 緑地被覆率の評価半径につ いて, 既往研究 ${ }^{16)}$ では $100 \mathrm{~m}$ とされているが, ダム湖の影響がな い湛水前の測定地点 1 25における晴天日の 5 時 17)の平均気温と 緑地被覆率 (評価半径 : $100 \mathrm{~m}, 200 \mathrm{~m}$ ) の相関を調べたところ, ともに $1 \%$ 水準で有意な相関が見られたが，評価半径 $200 \mathrm{~m}$ の方 が若干高い相関を示したため, 説明変数としては評価半径 $200 \mathrm{~m}$ の值を用いた（図一10)。

\section{2）日射環境}

局所的な日射環境については，まず後述の重回帰分析の対象之 した期間の代表日（2009年 8 月 17 日）の太陽軌道を算出し，標 高データを入力データとして仮想水平面日射量（以下，日射量） を各メッシュ（10m格子）において推定した。なお，ここでは常 時快晴を仮定している。次に，この各メッシュの日射量を，日の 出から当該時刻まで積算した值を積算日射量とし, 測定地点周辺 $100 \mathrm{~m}^{18)}$ の平均積算日射量を説明変数のひとつとした。日没時点 の積算日射量分布を図一11 に示寸。山沿いなど局所的に積算日射 量が小さいェリアが見られる。なおこの值は，日の出から当該時 刻までの積算日射量なので, 例えば, 夕方の 17 時と 18 時では, その分布傾向は大きく変化しない（それまでの積算日射量の寄与 が大きいため)。

3）ダム湖水面

前章の分析結果より, ダム湖の暑熱緩和効果の影響範井は風下 側 $500 \mathrm{~m}$ 程度と考えられることから, 各測定地点を中心とした半 径 $500 \mathrm{~m}$ の円の南側半円エリア内におけるダム湖面積割合を説明 変数のひとつとした。

\section{（2）重回帰分析結果}

湛水後の測定期間において昼夜とも晴天で, 南寄りの風が安定 して吹いていた 2009 年 8 月 17 日〜19 日を対象に，陸上の全測 定地点の時刻別平均気温を目的変数, 前節の 3 変数を説明変数と し重回帰分析を行った。結果を図-12 に示寸。なお，有意確率 $5 \%$ 水準で有意となった説明変数は・で示した。

午前は重相関係数が相対的に低く, $5 \%$ 水準で有意ではないが, 傾向としては，明け方（6 時）は緑地と日射環境の標準偏回帰係 数が大きい。山沿いなど日射の遮られる場所に比べ, 周囲が開け た場所で気温が上昇しているものと考えられる。午後 (15 時以降) は重相関係数が 0.4 以上となり, 時刻が進むにつれてやや大きく なる。標淮偏回帰係数を見ると, ダム湖水面が-0.4 程度と比較的 高い值となる。昼間に卓越寸る南寄りの風に対してダム湖の北岸 近傍で低温となる傾向が見られ，その暑熱緩和効果は周辺の緑地 による影響より大きいと考えられる。しかし，19 時以降は標準偏 回帰係数が有意ではなくなる。この要因としては, 風速が小さく なること，周辺気温とダム湖水温との差が小さくなることなどが 
考えられる。夜間から翌早朝（18 時～翌朝 6 時）は, 重相関係数 が 0.6 程度と比較的高い值で推移寸る。標準偏回帰係数は緑地が -0.5 程度で安定しており, 従来の研究でも指摘されているが, 周 辺に緑地が多い場所では，夏季夜間において冷涼な温熱環境が形 成されると言える。

以上より，風速が大きくなる昼間はダム湖の影響が見られ，風 が弱まり大気が安定する夜間になると，緑地の影響が大きくなる と考えられる。

\section{6. おわりに}

本研究では東広島市福富ダム周辺の住宅地を対象として，ダム 湛水前後の気温分布観測を行い，ダム湖の有寸る暑熱緩和効果の 把握を試みた。得られた主な知見を以下に記す。

- 5 時 (日最低気温時) の気温分布傾向は湛水前後で同様であ り，湛水の影響は小さいと考えられる。一方，14 時（日最 高気温時）の気温分布は，湛水前後で変化しており，湛水 後のみダム湖北部のエリアの気温が相対的に低い。これは 南からの風により，ダム湖で生成された冷気が，風下に運 ばれた影響であると考えられる。ダム湖水温が気温に比べ て低く，比較的風の強い昼間にダム湖の暑熱緩和効果が見 られるものと考えられる。

・ ダム湖からの距離 $500 \mathrm{~m}$ 程度以内で，且つダム湖の北側に 位置する測定地点の 14 時の平均気温が, 湛水後に相対的に 低下している。このことから，ダム湖の暑熱緩和効果の影 響範囲は風下 $500 \mathrm{~m}$ 程度と考えられる。この值は，ため池 や水田の影響範囲に比べ 2 倍以上であり，ダム湖はこれら に比べ影響範用が大きいと考えられる。

・風速が大きい時の方が，風下の測定地点の気温の低下幅が 大きい。このことより，風の強い昼間にダム湖の暑熱緩和 効果が，より大きく現れるものと考えられる。

- 重回帰分析結果より, ダム湖周辺住宅地において, ダム湖 の影響は昼間に大きく，早朝は日射環境，夜間から早朝に かけては緑地の影響が，それぞれ大きいものと考えられる。

以上，対象地におけるダム湖の暑熱緩和効果を把握することが できたが，3章（2）で述べたように夜間はダム湖水温が相対的 に高いため，周辺の夜間気温を上昇させる可能性が考えられる。 これは，ダム湖周辺で市街地整備を行う際にマイナスの影響とし て認識しておく必要があるものと考えられる。ただし，その一方 で, これは冬季においてはプラスの影響となり得るため, 冬季の 検討が別途必要と考えられる。

また本研究の成果をもとに，一般論として，ダム湖の暑熱緩和 効果を述べるにはデータが十分とは言えず，今後さらに観測事例 を増やして検討寸ることも必要と思われる。また，本対象地のよ うな山間部では冷気流の影響も考えられるので, 数值モデル等を 利用した冷気流の評価も必要と考えられる。

謝辞: 本研究は, 広島大学大学院工学研究科を修了した小川玩也 氏（現 : 株式会社 NTT ファシリティーズ）の修士論文の成果を 受けたものである。また，高橋一郎氏 (当時: 大成建設株式会社) には研究を進めるにあたり，多大なご協力をいただいた。さらに 気温観測に際しては，福富ダム管理事務所および東広島市の方々 に様々な形でご協力をいただいた。ここに記して謝意を表す。

\section{補注及び引用文献}

1) 内閣府・文部科学省・厚生労働省・農林水産省・国土交通省・気象庁・環境省 (2012) : 温暖化から日本を守る一適応への挑戦 $2012-$ : 環境省

2) 日本建築学会編 (2007) : ヒートアイランドと建築・都市一対策のビジョンと課題 - : 日本建築学会

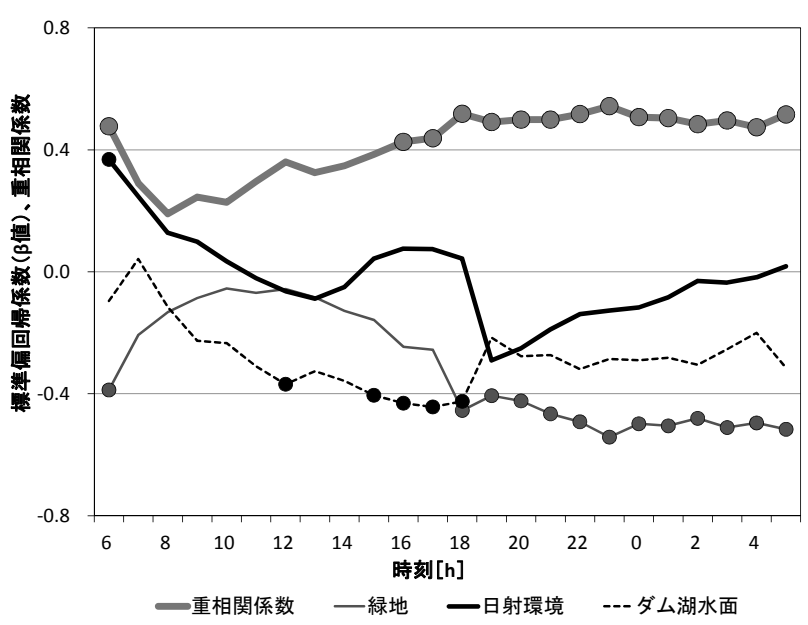

\section{図－12 重回帰分析結果（はは有意確率 5\%水準で有意）}

3）片山忠久ほか（1990）: 海岸都市における河川の暑熱緩和効果に関する研究 : 日本 建築学会計画系論文報告集 $418,1-9$

4）成田健一・鍵屋浩司（2010）: 臨海都市における中小河川の風の道としての効果一 東京・目黒川における微気象観測一：日本建築学会環境系論文集 75(653), 637-644

5）村川三郎・関根毅・成田健一・西名大作（1988）: 都市内河川が周辺の温熱環境に 及ぼす効果に関する研究 : 日本建築学会計画系論文報告集 393, 25-33

6）成田健一・植村明子・三坂育正 (2001) : 都市気候に及ぼす河川水の熱的影響に関 寸る実測研究一隅田川における熱収支と周辺影響の検討一: 日本建築学会計画系論文 集 545, 71-78

7）片山忠久ほか (1987）: 水面を有する市街地の熱環境に関する調査研究 : 日本建築 学会計画系論文報告集 $372,21-28$

8）深川健太・村川三郎・西名大作・嶋澤貴大（2008）：市街地ため池周辺における夏 季気温の形成 : 日本建築学会環境系論文集 73(626), 503-510

9）神田学・稲垣聡・日野幹雄（1991）: 夏期に森林・水面が果たす気候緩和効果に関 する実測とその周辺域への影響伝達機構に関寸る数值解析による検討:水工学論文集 $35,585-590$

10) 近藤明ほか (2001) : 数值モデルによる地域開発の微気象影響評価 : 空気調和・衛 生工学会論文集 83, 1-9

11）吉村不二男・平山元久・山崎信雄・田上周作 (1968) : ダム建設に伴う微気象变動 とミカンの寒害対策 : 高知大学学術研究報告 (自然科学) $16,79-96$

12) 近藤邦英・神井泰典 (1993) : ダム湖による気・水温環境の変化: 高知大学学術研 究報告 (自然科学) 42, 1-19

13）測定地点 1 では, 2006 年から 2009 年までの間, 季節毎の定期観測（毎年, 各季 節 20 日間ずつ気温を測定）を行っており，ここではそのデータを利用した。

14）広島大学工学部 $\mathrm{A} 2$ 棟 (8 階建) の塔屋の上で, 気温, 風向, 風速, 日射量の常時 観測が行われており，ここではそのデータを利用した。

15) 石原孟 (2002) : 複杂倠地形における局所風況の測定と数值予測: 日本風工学会誌 91 , $3-8$

16）小川环也ほか (2011)：山間地域における土地利用および日射環境が周辺の気温に 及ぼす影響に関する研究一実測結果と GIS を用いた分析一：日本建築学会技術報告 集 $17(35), 245-248$

17）文献 19 では, 周辺緑地率と気温の相関が最も高くなる時間帯が 3 時〜 6 時の早朝 であること, 文献 20 では周辺の自然被覆率と気温との相関が最も高くなる時間帯が 2 時〜 5 時の早朝であることがそれぞれ示されている。これらを参考に緑地の影響は 日の出直前に顕著に見られると考え，ここでは 5 時の気温を利用した。

18）既往研究 ${ }^{16)}$ と同様，日射量の評価半径は $100 \mathrm{~m}$ とした。

19) 入江彰昭 (2003) : 気温推定による緑地のヒートアイランド緩和効果に関寸る研究: ランドスケープ研究 66(5), 889-892

20) 竹林英樹・森山正和 (2005) : 海風の影響を受けたヒートアイランド現象 : 日本建 築学会技術報告集 $21 ， 199-202$ 